\title{
Development and Validation of a Questionnaire on Pharmacovigilance Knowledge among Health Professionals in Morocco
}

\author{
Zakaria Abidli ${ }^{1, *}$, Sara Jadda' ${ }^{1}$ Salma Ammor ${ }^{2}$, Abdelmajid Soulaymani' ${ }^{1}$ Abdelrhani Mokhtari', Rachida Soulaymani-Bencheikh³, \\ Hinde Hami ${ }^{1}$ \\ 'Laboratory of Genetics and Biometry, Faculty of Science, Ibn Tofail University, Kenitra, MOROCCO. \\ ${ }^{2}$ Department of Nephrology, Hassan II University Hospital Centre, Fez, MOROCCO. \\ ${ }^{3}$ Moroccan Anti-Poison and Pharmacovigilance Center, Rabat, MOROCCO.
}

\begin{abstract}
Background: Pharmacovigilance is one of the priority programs of the World Health Organization, with the aim of detecting the adverse effects of drugs. Morocco is one of the countries open to the world and was the first Arab and African country to participate in the international pharmacovigilance program. The purpose of this study is to develop and to validate a reliable and reasonable questionnaire, to measure knowledge and practices related to pharmacovigilance among health professionals in Morocco. Materials and Methods: This is a cross-sectional study that took place between January and March 2018. The study was based on a questionnaire. Pharmacovigilance experts validated the questionnaire and the final instrument was applied to health professionals practicing in different hospitals in Morocco. The statistical validation of the questionnaire is based on the calculation of the Cronbach Coefficient Index and a factor analysis. Results: The study involved 262 health professionals, including $39 \%$ of physicians, $35 \%$ of pharmacists and $26 \%$ of nurses. The average age of the participants was $35.2 \pm 8.4$ years old. The Cronbach alpha value of the set of items was 0.7 , similarly, the calculation of Cronbach's alpha showed a homogeneity of the different dimensions of the questionnaire used this for knowledge $(\alpha=0.6)$ and practices related to pharmacovigilance $(\alpha=0.6)$. On the knowledge side, $65 \%$ of participants correctly answered the
\end{abstract}

definition of pharmacovigilance, $81 \%$ were aware of its primary objective. We have noted that $52 \%$ of health workers, were aware of the existence of a national pharmacovigilance program in Morocco and $71 \%$ of the existence of the poison control center and pharmacovigilance of Morocco. The questionnaire has also shown that $28 \%$ of participants have reported an adverse reaction to the Poison Control and Pharmacovigilance Center of Morocco. Conclusion: Results showed that questionnaire is a well-structured, objective, valid and reliable in the Moroccan context, the questionnaire could be an instrument to assess knowledge and practice in Pharmacovigilance.

Key words: Validation, Questionnaire, Pharmacovigilance, Health Professionals, Morocco.

Correspondence

Dr. Zakaria Abidli,

Laboratory of Genetics and Biometry, Faculty of Science, Ibn Tofail University, Kenitra-14000, MOROCCO.

Phone: +21210932867

Email: abidli@outlook.fr

DOI: 10.5530/jyp.2019.11.80

\section{INTRODUCTION}

Adverse Drug Reactions (ADRs) are a serious problem affecting public health internationally. Indeed, in 1961 following the tragedy of thalidomide, ten developed countries collaborated and joined the World Health Organization (WHO) to implement the first seed of a new science, pharmacovigilance. ${ }^{1}$ According to $\mathrm{WHO}$, defined pharmacovigilance as "the science and activities related to the detection, evaluation, understanding and prevention of adverse effects or any other problem related to drugs". In 1968, a WHO international drug surveillance programme was launched the main objective of identifying pharmacovigilance signals as early as possible. The programme now contains more than 80 member countries from around the world who contribute to the writing of individual case safety reports in the WHO's global ICSR database system, VigiBase. ${ }^{3}$

At the continental level, 38 African countries are members of the international pharmacovigilance network (32 official members and 6 associate members). Despite this increase, pharmacovigilance in Africa is still considered low. ${ }^{4}$ This weakness is reflected in the rate of participation in the enrichment of the UMC database. In 2012, for example, the notification rate of African countries did not exceed $1.6 \%$ of the total number of notifications received. ${ }^{4}$ Morocco is one of the developed countries in the field of pharmacovigilance due to the Poison Control and pharmaco- vigilance Center, as well as a collaborating center of WHO. However, a study conducted by the Poison Control and Pharmacovigilance Center of Morocco showed that the average number of notifications was 205 reporting per 4 months with a rate of 87 reported cases / million inhabitants / year. ${ }^{5}$ This weakness of notifications could be influenced by several factors, among others the pharmacovigilance status. Indeed, so far, no national survey has been conducted to assess the knowledge and practices of health professionals regarding pharmacovigilance in Morocco. In this sense, our objective is to validate a questionnaire in pharmacovigilance, as well as to determine the state of knowledge and the practice of pharmacovigilance with health professionals in Morocco.

\section{MATERIALS AND METHODS}

This cross-sectional study took place between January and March 2018. The population studied concerns health professionals (doctors, nurses and pharmacists) working in various public hospitals in Morocco. The literature review ${ }^{6-8}$ concerning the assessment of the state of knowledge and Pharmacovigilance (PV) practices allowed us to use a scale of 25 items. The latter were submitted to the experts of the PV experts, of the professors of higher education for their scientific advice and to a linguist to judge the comprehensibility of the items because this scale will be

This is an open access article distributed under the terms of the Creative Commons Attribution-NonCommercial-ShareAlike 4.0 License, which allows others to remix, tweak, and build upon the work non-commercially, as long as the author is credited and the new creations are licensed under the identical terms. 
intended for an Arab-French speaking population. The advice of these experts allowed us to discard 9 items. A total of 16 items were selected for the assessment of the state of knowledge and practices related to PV. They are spread over 3 dimensions

- Knowledge on pharmacovigilance (8 items)

- $\quad$ Practice of pharmacovigilance (6 items)

- Factors leading to the practice of pharmacovigilance (2 items)

Similarly, we conducted a self-administered questionnaire that examined the socio-demographic and professional information of the participants in this study. Thus, a survey form was distributed personally and requested to be completed outside working hours. Data confidentiality was entrusted to the respondents by the anonymity of the participant. In our study, the process of validating the scale of the assessment of the knowledge state and the practice of PV among health professionals is based on two stages. Initially, we calculated the reliability of the entire questionnaire and the three dimensions of the scale by Cronbach's alpha. Next, exploratory factor analyzes were performed. Statistical analyzes were done by the Statistical Package for the Social Sciences (SPSS, version 21). The data collected were therefore the subject of exploratory analyzes to determine the dimensionality of the scale of assessment of the knowledge state and the practice of PV among health professionals in Morocco. Principal component factor analysis (PCF) is the most efficient method for synthesizing information and uncovering the underlying structure of a concept since it is a method for analyzing multi-variate data. Which makes it possible to simultaneously explore the relationships that exist between several variables studied. ${ }^{9}$ In our study we used the Kayser Meyer Olkin (KMO) test. A KMO of less than 0.5 is unacceptable, 0.5 is low, more than 0.6 is acceptable, 0.7 is average, 0.8 is meritorious and 0.9 is excellent ${ }^{10}$ and Bartlett's sphericity test to assess the potential effectiveness of the PCR studied. For a factor analysis to be feasible the Bartlett test must be significant $(p<0.05),{ }^{11}$ so we have calculated Cronbach's alpha to verify the reliability and homogeneity between the items on the scale. Measured. An alpha between 0.6 and 0.8 is acceptable for an exploratory study. ${ }^{12,13}$

\section{RESULTS}

\section{Sociodemographic and professional profile of the study population}

The population of our study covers 262 health professionals, including $39 \%$ of physicians, $35 \%$ of pharmacists and $26 \%$ of nurses. The average age of the participants was $35.2 \pm 8.4$ years old. Women who participated in this study are more than men with a percentage of $69 \%$ are Health professionals working in rural areas are represented by a percentage of $21 \%$. Participants with an average experience of $9.1 \pm 5.5$ years, ranging from one year to 25 years of experience (Table 1).

\section{Validation of the questionnaire}

\section{a. Internal reliability of the questionnaire items}

The Cronbach alpha value of the set of items was 0.7 , similarly, the calculation of Cronbach's alpha showed a homogeneity of the different dimensions of the questionnaire used this for knowledge $(\alpha=0.6)$ and practices related to PV $(\alpha=0.6)$ (Table 2).

\section{PV: Pharmacovigilance}

To make a factorial analysis of the questionnaire, we took into consideration the value of the KMO index and Bartlett's sphericity test. For our study, the KMO index was $0.6>0.5$, which shows an acceptable value for doing the factor analysis, so, Bartlett's sphericity test is highly significant. (Table 3)
Table 1: Professional and demographic parameters of our population.

\begin{tabular}{ccc} 
Variables & Number & Percentage \\
\hline Status & 101 & $39 \%$ \\
Physician & 92 & $35 \%$ \\
Pharmacist & 69 & $26 \%$ \\
Nurse & & \\
Mid exercise & 55 & $21 \%$ \\
Rural & 207 & $79 \%$ \\
Urban & & \\
Gender & 82 & $31 \%$ \\
Masculine & 180 & $69 \%$ \\
Feminine & & \\
\hline
\end{tabular}

Table 2: Cronbach alphas values of all items and dimensions of the questionnaire.

\begin{tabular}{ccc}
\hline & Cronbach's alpha & Items \\
\hline Sets of items & 0.7 & 14 \\
Knowledge in PV & 0.6 & 9 \\
PV practices & 0.6 & 5 \\
\hline
\end{tabular}

Table 3: The KMO index (Kaiser - Mayer - Olkin) and Bartlett Test.

\begin{tabular}{|c|c|c|}
\hline & & Valeur \\
\hline \multicolumn{2}{|c|}{ KMO index } & 0.6 \\
\hline \multirow[t]{3}{*}{ Bartlett's sphericity test } & Chi-square approx. & 1181.5 \\
\hline & Ddl & 91 \\
\hline & Signification & 0.00 \\
\hline
\end{tabular}

To study the factorial structure of the collected data, we opted for a Principal Component Analysis (PCA), the latter was done with varimax rotation on all the items of the questionnaire.

This analysis identified four factors that account for $60 \%$ of the total variance. The first factor consisting of three items (item 11, item 12 and item 13) explains $17.3 \%$ of the inertia, the second factor consisting of three items (item 3, item 4 and item 6) explains $16.3 \%$ of the observed variance, the third factor consisting of four items (item 5 , item 7 , item 8 and item 9) explains $15.3 \%$ of the total variance and the fourth factor consisting of four items (item 1, item 2, item 10, item 14) explains 11.1 $\%$ of observed variance. The homogeneity of items allowed us to name the first factor "Practice of PV", the second factor "Training in PV", the third factor "Knowledge of PV at the national level" and the fourth factor "Academic knowledge of PV". The factor analysis allowed to retain a dimension for the practice (factor 1 ) and three dimensions for the state of knowledge in the field of PV (factor 2, factor 3 and factor 4). To test the reliability of these new dimensions of the questionnaire we determined the Cronbach's alpha, this demonstrated a very high homogeneity between the items (Table 4 ).

\section{Profile of the knowledge state and the practice of pharmacovigilance in our population.}

\section{a. Knowledge state in pharmacovigilance}

In terms of knowledge, $65 \%$ of participants responded correctly to the definition of PV according to the World Health Organization, 81\% were aware of its main objective. $39 \%$ of health professionals studied PV at the initial level and only $20 \%$ of participants attended continuing education. We have noted that $52 \%$ of health workers were aware of the existence 
Table 4: Cronbach's alpha for the new dimensions of the questionnaire.

\begin{tabular}{|c|c|c|c|}
\hline Dimension & Sub-dimensions & Items & $\begin{array}{c}\text { Cronbach's } \\
\text { alpha }\end{array}$ \\
\hline \multirow[t]{2}{*}{ Practice of PV } & & $\begin{array}{c}\text { item } 11 \text {, item } 12 \text { et } \\
\text { item } 13\end{array}$ & 0.72 \\
\hline & Training in PV & $\begin{array}{c}\text { item } 3 \text {, item } 4 \text { et } \\
\text { item } 6\end{array}$ & 0.71 \\
\hline \multirow[t]{2}{*}{$\begin{array}{l}\text { Knowledge } \\
\text { state of PV }\end{array}$} & $\begin{array}{l}\text { Knowledge of PV at } \\
\text { the national level }\end{array}$ & $\begin{array}{c}\text { item } 5 \text {, item } 7 \text {, item } \\
8 \text { et item } 9\end{array}$ & 0.69 \\
\hline & $\begin{array}{c}\text { Academic knowledge } \\
\text { of PV }\end{array}$ & $\begin{array}{c}\text { item } 1 \text {, item } 2 \text {, item } \\
10 \text { et item } 14\end{array}$ & 0.75 \\
\hline
\end{tabular}

Table 5: Distribution of responses for each dimension 1 item (knowledge state).

\begin{tabular}{|c|c|c|c|}
\hline Item & Questions & $\begin{array}{c}\text { Yes } \\
\mathrm{n}(\%)\end{array}$ & $\begin{array}{c}\text { No } \\
\mathrm{n}(\%)\end{array}$ \\
\hline 1 & Do you know what pharmacovigilance is? & $171(65 \%)$ & $91(35 \%)$ \\
\hline 2 & $\begin{array}{c}\text { Do you have an idea about the objectives } \\
\text { of pharmacovigilance? }\end{array}$ & $211(81 \%)$ & $51(19 \%)$ \\
\hline 3 & $\begin{array}{l}\text { Have you studied pharmacovigilance } \\
\text { during your initial training? }\end{array}$ & $102(39 \%)$ & $160(61 \%)$ \\
\hline 4 & $\begin{array}{l}\text { Have you participated in ongoing training } \\
\text { on pharmacovigilance? }\end{array}$ & $52(20 \%)$ & $210(80 \%)$ \\
\hline 5 & $\begin{array}{c}\text { Do you think that pharmacovigilance } \\
\text { should be taught in detail to health } \\
\text { professionals? }\end{array}$ & $258(98 \%)$ & $4(2 \%)$ \\
\hline 6 & $\begin{array}{l}\text { Where is the International Monitoring } \\
\text { Center for Adverse Drug Reactions? }\end{array}$ & $49(19 \%)$ & $213(81 \%)$ \\
\hline 7 & $\begin{array}{c}\text { Do you know about the existence of a } \\
\text { national pharmacovigilance program in } \\
\text { your country? }\end{array}$ & $135(52 \%)$ & $127(48 \%)$ \\
\hline 8 & $\begin{array}{c}\text { Do you know that there is a Poison } \\
\text { Control and Pharmacovigilance Center in } \\
\text { Morocco? }\end{array}$ & $185(71 \%)$ & $77(29 \%)$ \\
\hline 9 & $\begin{array}{c}\text { Are you aware of the occurrence of an } \\
\text { adverse drug event? }\end{array}$ & $236(90 \%)$ & $26(10 \%)$ \\
\hline
\end{tabular}

Table 6: Responses for each item in dimension 2 (Practice of pharmacovigilance).

\begin{tabular}{|c|c|c|c|}
\hline Items & Questions & $\begin{array}{c}\text { Yes } \\
n(\%)\end{array}$ & $\begin{array}{c}\text { No } \\
n(\%)\end{array}$ \\
\hline 10 & $\begin{array}{c}\text { Have you ever received a patient with an } \\
\text { adverse event related to drugs or other } \\
\text { health products? }\end{array}$ & $237(90 \%)$ & $25(10 \%)$ \\
\hline 11 & $\begin{array}{c}\text { Have you ever reported an adverse event } \\
\text { to the National Center / Department / } \\
\text { Pharmacovigilance Unit? }\end{array}$ & $74(28 \%)$ & $187(72 \%)$ \\
\hline 12 & $\begin{array}{c}\text { Have you ever seen the adverse reaction } \\
\text { reporting form? }\end{array}$ & $65(25 \%)$ & 197(75\%) \\
\hline 13 & $\begin{array}{l}\text { Have you ever received training on how to } \\
\text { report adverse drug reactions? }\end{array}$ & $9(3 \%)$ & $253(97 \%)$ \\
\hline 14 & $\begin{array}{l}\text { Which of the following methods is } \\
\text { commonly used by the health professional } \\
\text { to monitor the adverse effects of new } \\
\text { drugs after they are introduced to the } \\
\text { market? }\end{array}$ & $9(3 \%)$ & $253(97 \%)$ \\
\hline
\end{tabular}

of a national PV program in Morocco and $71 \%$ of the existence of the poison control and pharmacovigilance center in Morocco. Only 19\% of participants knew that the International Monitoring Center for Adverse Reactions was in Sweden and $98 \%$ of participants thought that pharmacovigilance should be taught in detail to health professionals. For the concept of an adverse event, 90\% of investigations were aware of the occurrence of an adverse drug event. (Table 5)

\section{b. Practice of pharmacovigilance}

On the practical side of PV, $28 \%$ of the participants who reported an adverse reaction to the Poison Control and Pharmacovigilance Center of Morocco, as well as $24 \%$ of respondents who saw the adverse reaction reporting form. We have noted that $3 \%$ of respondents who received training on how to report adverse drug reactions and the same percentage for participants who knew about the method used to determine the relationship between drug effects and drug use (Imputability), as well as we found that $90 \%$ of the respondents had already received a patient with an adverse event related to the use of drugs or other health products. (Table 6)

\section{DISCUSSION}

Adverse drug reactions are a real public health problem at the national and international levels. For this reason, health professionals need to be aware of PV. To our knowledge, this is the first study in Morocco with regard development and validation of a questionnaire on PV knowledge among health professionals. In our study, the response rate was very good $(87.3 \%)$ and was similar to those reported in other studies from the Arabia countries. ${ }^{14-16}$ On an international scale, typical participant response rates for such studies vary quite extensively, from approximately betwenn 50 to $97 \%$, as a function of the study population and how the questionnaire was. ${ }^{17,18}$ These differences in participation rates could be due to lack of time and overwork. Participants may have felt uncomfortable responding due to their lack of knowledge of the basic concepts of PV and ADRs and therefore refused to participate. ${ }^{18}$ At the level of pharmacovigilance knowledge, Results from this study show that the most of health professionals had good knowledge regarding the concept of PV and ADRs in terms of their definitions and their object if, this result is consistent with a study conducted in India and in Saudi Arabia. ${ }^{19,16}$ On the other hand, a study carried out in Cameroon showed that the PV knowledge score is very low. ${ }^{20}$ These differentiations in levels of knowledge about PV could be due to academic PV programs for each country. The majority (72\%) of participant do know the Anti-poison and Pharmacovigilance Center of Morocco (MAPPC); however, we noted that $28 \%$ of them did not report an adverse reaction during their professional career. These results are consistent with internationally published studies also revealed a low reporting rate: Qatar $(29.3 \%),{ }^{21}$ Istanbul (21\%), ${ }^{22}$ Jordan $(19.5 \%)^{23}$ and Northern China ${ }^{24}(14.6 \%)$. A meta-analysis done in India on the knowledge and practice of PV, has shown that 28.7\% (95\%CI: 16.4-40.9; $p<0.001$ ) of them were not interested in reporting ADRs. ${ }^{25}$ These low rates of adverse drug reaction reporting may be due to several factors. The main reasons for under-reporting ADRs are lack of time, lack of knowledge about reporting mechanisms, lack of awareness of the existence of the national pharmacovigilance system, belief that the ADR was already well known, doubt about the importance of ADRs. The main reasons for under-reporting ADRs are lack of time, lack of knowledge about reporting mechanisms, lack of awareness of the existence of the national pharmacovigilance system, belief that the ADR was already well known, doubt about the importance of ADRs. ${ }^{26}$ According to the literature review, studies have been demonstrating the state of knowledge in pharmacovigilance has an impact on the reporting of adverse effects. ${ }^{27}$

The lack of awareness of a national ADR reporting centre or lack of knowledge of ADR reporting process has also been reported in KSA, 
Kuwait, in Iran and Jordan. We have $48 \%$ in our study who were not aware that there is a national pharmacovigilance program, although the Moroccan Minister of Health asks health professionals and the pharmaceutical industry to report adverse drug-related reactions in Ministerial Circular No. 2DR / 10 of 1992 and in the text of Law 17-04 of 2005 on medicines. ${ }^{28}$ In our study, the majority of participants had no knowledge of reporting procedures, similar to studies in developing and developed countries, In China, $71 \%$ of health professionals had no knowledge of reporting procedures. ${ }^{29}$ In Malaysia, almost $40 \%$ of participants were not aware of the existence of a national adverse drug reaction reporting system. ${ }^{30}$

In terms of knowledge assessment and PV practice, to our knowledge, this is the first study in in Arab countries with regard development and validation of a questionnaire on pharmacovigilance in the Arab context. Validation of the questionnaire was based on Churchill's paradigm. ${ }^{31-33}$ In Mexico, a study conducted on the validation of the pharmacovigilance questionnaire determined a very high internal homogeneity of items with a Cronbach index of $0.7 .^{34}$ In our study, the internal reliability of the questionnaire was important with a Cronbach index of 0.7.

\section{CONCLUSION}

The results show that health professionals in Morocco have a lack of knowledge about how to report adverse drug reactions. There is an urgent must carry out awareness campaigns for health professionals, in the interest of reporting adverse reactions.

\section{ACKNOWLEDGEMENT}

The authors are pleased to acknowledge the Moroccan AntiPoison and Pharmacovigilance Center (MAPPC) for providing the facilities for the research. In addition to the entire research team of the Genetics and Biometry Laboratory at Ibn Tofail University. This work was carried out within the framework of the Priority Project PPR-B-Mokhtari-FS-UIT Kenitra.

\section{CONFLICT OF INTEREST}

The authors declare no conflict of interest.

\section{ABBREVIATIONS}

KMO index: Kaiser - Mayer - Olkin; PV: Pharmacovigilance; WHO: World Health Organization.

\section{REFERENCES}

1. Kim JH, Scialli AR. Thalidomide: The tragedy of birth defects and the effective treatment of disease. Toxicol Sci Off J Soc Toxicol. 2011;122(1):1-6.

2. World Health Organization (WHO). Pharmacovigilance :assurer la sécurité d'emploi des médicaments. 2004. [cited 2 juin 2019]. Available from: https:// apps.who.int/medicinedocs/pdf/s6165f/s6165f.pdf

3. Lindquist M. Vigi Base, the WHO Global ICSR Database System: Basic Facts. Drug Inf J. 2008;42(5):409-19.

4. Isah AO, Pal SN, Olsson S, Dodoo A, Bencheikh RS. Specific features of medicines safety and pharmacovigilance in Africa. Ther Adv Drug Saf. 2012:3(1):25-34

5. Doctinews. National Pharmacovigilance Centre (CNPV) report cancelled. 2015 [cited 2 juin 2019]. Available from: https://www.doctinews.com/index.php/ doctinews/zoom/item/4576-centre-national-de-pharmacovigilance-cnpv

6. Kharkar M, Bowalekar S. Knowledge, attitude and perception/practices (KAP) of medical practitioners in India towards Adverse Drug Reaction (ADR) reporting Perspect Clin Res. 2012;3(3):90-4.

7. Upadhyaya P, Seth V, Moghe WV, Sharma M, Ahmed M. Knowledge of adverse drug reaction reporting in first year postgraduate doctors in a medical college. Ther Clin Risk Manag. 2012;(8):307-12.

8. Rehan HS, Sah RK, Chopra D. Comparison of knowledge, attitude and practices of resident doctors and nurses on adverse drug reaction monitoring and reporting in a tertiary care hospital. Indian J Pharmacol. 2012;44(6):699-703.

9. Field A. Discovering statistics using SPSS. $3^{\text {rd }}$ ed. Third edition, editors. New York SAGE Publications. 2009.

10. Stewart DW. The Application and Misapplication of Factor Analysis in Marketing Research. J Mark Res. 1981;18(1):51-62.

11. DMSP Research Centre. Proposition of a contextualized scale of measurement team learning: An Exploratory Analysis. Université de Paris-Dauphine, Paris, France. 2003. [cited 10 juin 2019]. Available from: https://basepub.dauphine.fr/ bitstream/handle/123456789/4299/CR321.pdf\%3Bsequence\%3D1

12. Johnson RA, Wichern DW. Applied Multivariate Correspondence Analysis. $6^{\text {th }}$ edition. Prentice-Hall, editors. USA: Upper Saddle River, NJ. 2007.

13. Yves E, Pras B, Roux E. Market-Etudes et recherches en marketing. $2^{\text {nd }}$ ed.Dunod, editors. France: Gestion Sup. 2003

14. Jose J, Jimmy B, Al-Ghailani ASH, AIMajali MA. A cross sectional pilot study on assessing the knowledge, attitude and behavior of community pharmacists to adverse drug reaction related aspects in the Sultanate of Oman. Saudi Pharm J. 2014;22(2):163-9.

15. Abdel-Latif MMM, Abdel-Wahab BA. Knowledge and awareness of adverse drug reactions and pharmacovigilance practices among healthcare professionals in Al-Madinah Al-Munawwarah, Kingdom of Saudi Arabia. Saudi Pharm J 2015;23(2):154-61.

16. Mahmoud MA, Alswaida Y, AlshammariT, Khan TM, Alrasheedy A, Hassali MA et al. Community pharmacists' knowledge, behaviors and experiences about adverse drug reaction reporting in Saudi Arabia. Saudi Pharm J. 2014;22(5):411-8.

17. Green CF, Mottram DR, Rowe PH, Pirmohamed M. Attitudes and knowledge of hospital pharmacists to adverse drug reaction reporting. Br J Clin Pharmacol. 2001;51(1):81-6.

18. Herdeiro MT, Figueiras A, Polónia J, Gestal-Otero JJ. Influence of pharmacists' attitudes on adverse drug reaction reporting: A case-control study in Portugal. Drug Saf. 2006;29(4):331-40.

19. Alsaleh FM, Alzaid SW, Abahussain EA, BayoudT, Lemay J. Knowledge, attitude and practices of pharmacovigilance and adverse drug reaction reporting among pharmacists working in secondary and tertiary governmental hospitals in Kuwait. Saudi Pharm J. 2017;25(6):830-7.

20. Djoussé NC. Knowledge, attitudes and practices of health professionals on pharmacovigilance notification: Presses Académiques Francophones, editors France : Presses Académiques Francophones; 2015

21. Wilbur K. Pharmacovigilance in Qatar: A survey of pharmacists. East Mediterr Health J. 2013;19(11):930-5

22. Toklu HZ, Uysal MK. The knowledge and attitude of the Turkish community pharmacists toward pharmacovigilance in the Kadikoy district of Istanbul. Pharm World Sci PWS. 2008;30(5):556-62

23. Suyagh M, Farah D, Abu FR. Pharmacist's knowledge, practice and attitudes toward pharmacovigilance and adverse drug reactions reporting process. Saud Pharm J. 2015;23(2):147-53

24. Su C, Ji H, Su Y. Hospital pharmacists' knowledge and opinions regarding adverse drug reaction reporting in Northern China. Pharmacoepidemiol Drug Saf. 2010;19(3):217-22.

25. Bhagavathula AS, Elnour AA, Jamshed SQ, Shehab A. Health Professionals' Knowledge, Attitudes and Practices about Pharmacovigilance in India: A Systematic Review and Meta-Analysis. PloS One. 2016;11(3):e0152221.

26. Lee A, Thomas SHL. Adverse drug reactions. Clin Pharm Ther. 2003;33-4

27. Remesh $A$. Identifying the reasons for under reporting of ADR: A cross sectional survey. Res J Pharm Biol Chem Sci. 2012;3(4):1379-86.

28. Organization WHO. Morocco - Profile of the Country's Pharmaceutical Sector (2011 Questionnaire). The Institution, Geneva, Switzerland. 2011. [cited 6 juin 2019]. Available from: http://apps.who.int/medicinedocs/fr/m/abstract/ Js19875fr/.(French)

29. Li Q, Zhang S, Chen H, Fang S, Yu X, Liu D, et al. Awareness and attitudes of healthcare professionals in Wuhan, China to the reporting of adverse drug reac tions. Chin Med J. 2004;117(6):856-61.

30. Aziz Z, Siang TC, Badarudin NS. Reporting of adverse drug reactions: Predictors of under-reporting in Malaysia. Pharmacoepidemiol Drug Saf. 2007;16(2):223-8.

31. Churchill GA. A Paradigm for Developing Better Measures of Marketing Constructs. J Mark Res. 1979;16(1):64-73.

32. Fabrigar LR, Wegener DT, MacCallum RC, Strahan EJ. Evaluating the use of exploratory factor analysis in psychological research. Psychol Methods. 1999;4(3):272-99.

33. Campoy E, Durrieu F, Roussel P, Akremi AE. Structural equation methods: Research and applications in management. Economica, editors. Paris: Economica. 2002:1:303-46

34. Novoa-Heckel GP, Asbún-Bojalil J. Design and Validation of a Questionnaire in Pharmacovigilance. Int J Med Sci Clin Invent. 2019;3(10) 